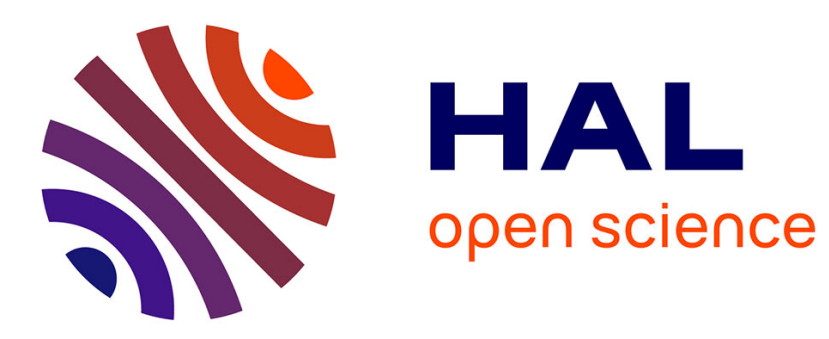

\title{
Characteristics of the flesh and quality of products of catfishes
}

Benoit Fauconneau, Michel Laroche

\section{To cite this version:}

Benoit Fauconneau, Michel Laroche. Characteristics of the flesh and quality of products of catfishes. Aquatic Living Resources, 1996, 9, pp.165-179. 10.1051/alr:1996051 . hal-02687954

\section{HAL Id: hal-02687954 https://hal.inrae.fr/hal-02687954}

Submitted on 1 Jun 2020

HAL is a multi-disciplinary open access archive for the deposit and dissemination of scientific research documents, whether they are published or not. The documents may come from teaching and research institutions in France or abroad, or from public or private research centers.
L'archive ouverte pluridisciplinaire HAL, est destinée au dépôt et à la diffusion de documents scientifiques de niveau recherche, publiés ou non, émanant des établissements d'enseignement et de recherche français ou étrangers, des laboratoires publics ou privés. 


\title{
Characteristics of the flesh and quality of products of catfishes
}

\author{
Benoît Fauconneau and Michel Laroche
}

INRA, Growth Differentiation Quality, Fish Physiology, Campus de Beaulieu, 35042 Rennes cedex, France.

INRA, LEIMA, me de la Géraudière B.P. 527, 44026 Nantes cedex 03, France.

Received July 6, 1995.

Fauconneau B., M. Laroche. In: The biology and culture of catfishes. M. Legendre, J.-P. Proteau eds. Aquat. Living Resour., 1996, Vol. 9, Hors série, 165-179.

Abstract

Specificities of the structural, chemical, physical and sensory characteristics of the flesh are reviewed and related to different aspects of flesh quality. Potential for processing of catfish is high in terms of mechanization but rather low in terms of processing yields. The variability observed in body conformation traits supports the possibility to improve processing yields by genetic sclection. Little is known on the structure of catfish flesh but a higher cohesiveness due both to greater connective tissue strength and probably a greater homogeneity of muscle tissues is observed, compared to other freshwater species. Although the presence of adipose tissues has not been demonstrated, intermuscular adipose tissues contributes with red muscle to lipid deposits in commercial sizc. Lipid content in catfish flesh increases with age but even at commercial size it is still lower than what is reported in other cultured fish. There is however a tendency in recent years for an increase in lipid content in catfish flesh due to increased lipid content in the diet. Thus, further information on the control of lipid deposits is required in future especially in a view to improve taste and processing yields. The lipid composition of neutral lipids reflects that of the diet with high levels of monounsaturated fatty acids and a low w3/w6 ratio.

Flesh colour is very subtle but it could be controlled either by the use of pigment supplementation in the diet or by rearing non pigmented catfish. Other physical characteristics of the flesh are very stable during the cooking process. Cooked flesh has a relatively low water-holding capacity and a low resistance to mechanical stress (compression, extrusion) thus contributing to the juiciness and tenderness of the flesh.

The sensory characteristics of the flesh are somewhat neutral but consumers are able to detect the specific characteristics of different species such as Channel catfish, African catfish and European catfish. Significant efforts to standardize the sensory evaluation of Channel catfish have been made in the USA but flavor and aroma of catfish seem to be more related to the fish itself than to other factors such as the diet composition. New data is available on off-flavors related to geosmin and methyl-iso-borneol. Specific control of the phytoplankton species which produce these compounds appears to be possible.

Storage on ice affects the flesh acceptability as it does for other fish species, but catfish flesh seems to be stable at least physically during freezing. Traditional processing is used for preservation of the flesh. New processing methods have been tested for the diversification of catfish products or to produce substitutes for other animal products. Catfishes are generally shown to be suitable for processing.

Keywords: Fish culture, feeding experiments, flavor, fish fillets, catfish.

Caractéristiques de la chair et qualité des produits chez les poissons-chats.

Résumé

Les caractéristiques morphologiques, structurales, chimiques, physiques et sensorielles spécifiques de la chair des poissons-chats sont mises en évidence et leurs implications sur la qualité sont étudiées. Les poissons-chats présentent d'excellentes aptitudes à la transformation mécanique mais les rendements sont faibles. L'existence d'une variabilité de conformation corporelle permet de penser que l'amélioration, par sélection génétique des rendements de transformation, est possible. Il existe peu de données sur la structure de la chair des poissons-chats. Celle-ci est caractérisée par une bonne cohésion résultante à la fois d'une grande résistance du tissu conjonctif et probablement d'une plus grande homogénéité du tissu musculaire 
comparée à la chair des autres poissons d'élevage. Bien que la présence de tissus adipeux ne soit pas démontrée, les tissus adipeux intermusculaires contribuent certainement avec le muscle rouge aux dépôts de lipides obscrvés ches les Siluriformes de taille commerciale.

La teneur en lipides de la chair augmente avec l'âge mais reste très inférieure même aux stades commerciaux à celle de la chair des autres poissons d'élevage. Une tendance récente à l'augmentation de la teneur en lipides de la chair, liée à une augmentation de la teneur en lipides de l'aliment, est observée chez le poisson-chat. Un contróle de l'état d'engraissement qui conditionne notamment les rendements de transformation et le goût des produits serait done nécessaire dans l'avenir. La composition en acides gras des lipides neutres refiète celle des lipieles de l'aliment avec des tencurs élevées d'acides gras monoinsaturés et un rapport $w 3 / w 6$ faible.

La couleur de la chair est très subtile et peut ĉtre contrôlée particllement par l'apport de précurscurs de pigments dans l'alimentation ou par l'élevage de souches non pigmentées comme c'est le cas pour lo poisson-chat. Les caractéristiques physicques de la chair restent stables à la cuisson. Lá chair cuite présente une faible capacité de rélention d'eau et une faible résistance mécanique (à la compression et à l'extrusion) ce qui participe à la jutosité et à la tendreté de la chair. Les caractéristiques sensorielles de la chair sont relativement neutres mais les jurys de dégustateurs peuvent détecter les caractéristiques spécifiques de différentes espèces : poisson-chat américain lctalurus sp., poisson-chat africain, Clarias et silure européen, Silurus sp. De grands efforts ont été faits pour standardiser l'évaluation sensoriclle du poisson-chat aux États-Unis. La llaveur et l'arôme du poisson-chat semblent toutefois plus dépendants des caractéristiques intrinsèques à l'espèce que de la composition de l'aliment. Des données nouvelles ont été obtenues sur les "off-flavors" dûes à la préscnce de composés comme la géosmine et le méthyl-iso-burnéol. Lc contrôle spécilique de certaines espèces du phyloplancton responsables de la production de ces composés semble envisageable.

Le stockage dans la glace modific l'acceptabilité de la chair qui, toutefois, semble stable physiquement au cours de la congélation. Différents types de transformation de la chair ont été développés. Les procédés tradjtionncls permettent de faciliter la conservation. De nouveaux procédés ont été testés spécifiquement sur le lctalurus sp. pour la diversification de la valorisation des prodiuts a base de poisson ou pour obtenir des produits de substitution d'autres produits animaux. Les Siluroidei présentent une grande aptitude à tous ces types de Iransformation.

Mots-clés : Élevage de poisson, alimentation, filets de poisson, Siluroidei.

\section{INTRODUCTION}

Improvement of fish performance by the control of the main functions (reproduction, nutrition, adaptation, etc.) is exploited by a clear definition of fish fiesh quality. In advanced fish industry such as those for salmonids in northern Europe or catfish in the USA but also in traditional fish breeding processes such as those used for cyprinids in central and eastern Europe and in Asia, or milkfish in Asia, more and more emphasis has been placed on the definition and improvement of flesh quality but only once a given level of performance has been reached. In recently developed production areas (flatfish, Sparidae, some Siluridae) the same effort to achieve better knowledge of quality factors in these now products accompagnied the improvement of production itself.

Quality is often seen from a practical point of view i.e acceptability of the end product of the production process. However, the quality of these end products is the results of a long chain of processes: production itself which is a combination of intrinsic characteristics of fish and their expression in a given environment, slaughtering, post mortem changes, processing, storage. Basic knowledge on how these different steps affect end product quality is thus required.

Furthermore, the quality of fish flesh covers different complementary aspects. From the consumer point of vicw there are three important aspects in the quality of a product: safety, nutritional value and sensory characteristics. In cultured fish, the complete control of slaughtering and storage period largely decreases risks of bacterial development although specific risks for consumers due to intensive breeding are still present. Quality definition of cultured fish is thus mainly focused on its nutritional and sensory aspects. The fish industry, fish farmers included, has its own definition of the quality of a product which comprises its processing capability.

These different aspects of fish flesh quality are reviewed from data available in the litterature. We present valuable information on the factors which affect flesh quality and open prospects for its control. This revicw is devoted to Siluriforms which include a large variety of species. There is however very little published data on Siluriforms and most of it is devoted to catfish. Catfish are thus presented as a reference model and additional information on other Siluriforms is also given.

The characteristics of Siluriforms are specific in terms of body shape, flesh structure and flesh taste compared to other fish. These specificities and their consequences both for processing and for the expression of sensory characteristics are specifically illustrated in this review. 


\section{GROWTH, BODY SHAPE AND PROCESSING SUITABILITY}

Siluriforms are generally dressed by evisceration, heading and skinning because of aspect (Channel catfish, African catfish) or size (European catfish) of whole fish. The evisceration yield amounts $90 \%$ of fresh body weight depending on the species and final dressing yield amounts $60 \%$ (table 1). The different dressing stages could be mechanized. This is already used successfully with Channel catfish and for the proccssing of other Siluriforms including European catfish.

The evisceration yield is rather high. It depends mainly on the development of visceral fat which is slight in catfish ( 2 to $3 \%$ body weight) compared to that observed in salmonids. However, large differences in visceral fat development between strains and hybrids ( 3.5 to $12.1 \%$ ) have been observed in catfish (Smitherman et al., 1983). The control of fat deposits in the different parts of catfish will be analysed in another chapter but the use of high fat diets does appears to have a dramatic effect on visceral fat.

The yields of other dressing stages (heading and skinning) are rather low and this is mainly the consequence of the conformation (large head) and the thickness of skin (Yamaguchi et al, 1976) of catfish.

Little information is found in the literature concerning the variability of such yields and especially their potential relationship with body shape. The final dress out percentage seems to be more dependent on visceral percentage than on head percentage (Dunham et al., 1983). This is probably related to the priority in the development of adipose tissues at that commercial size. The production of triploid fish with reduced gonad development, at lcast in females (Chrisman et al., 1983), leads to a significant increase in dress out percentages in large fish (Christman et al., 1983) but not in small commercial sizes $(500 \mathrm{~g}$ ) (Wolsters $e t$ al., 1991) and this is also probably due to the larger development of visceral fat at small sizes.

Table 1. - Dressing yields (\% body weight) in commercial size farmed silurids.

\begin{tabular}{|c|c|c|c|c|}
\hline & $\begin{array}{l}\text { Evisceration } \\
\%\end{array}$ & $\begin{array}{l}\text { Dressing } \\
\%\end{array}$ & $\begin{array}{l}\text { Fillering } \\
\%\end{array}$ & Reference \\
\hline \multicolumn{5}{|l|}{ Channel catfish } \\
\hline $160-190 \mathrm{~g}$ & & $60-63$ & & Wcbster et al. 1992 \\
\hline $200-300 \mathrm{~g}$ & & 68 & & El-Ibiary and Joyce 1978 \\
\hline $200-220 \mathrm{~g}$ & & $52-54$ & & Wcbster et al. 1993 \\
\hline $460-520 \mathrm{~g}$ & & $58-61$ & & $\mathrm{Li}$ and Lovell 1992 \\
\hline $480-500 \mathrm{~g}$ & & $55-57$ & $27-28$ & Wolters et al. 1991 \\
\hline $610 \mathrm{~g}$ & & 61 & 31 & Clement and Lovell 1994 \\
\hline $600-700 \mathrm{~g}$ & & $58-62$ & $32-35$ & Grant and Robinette 1992 \\
\hline $900 \mathrm{~g}$ & 92 & & 26 & Manthey et al. 1988 \\
\hline $1300-1600 \mathrm{~g}$ & & $62-63$ & $36-37$ & Grant and Robinette 1992 \\
\hline $1580-1860 \mathrm{~g}$ & & $66-67$ & & $\mathrm{Li}$ and Lovell 1992 \\
\hline \multicolumn{5}{|l|}{ Ictaluridae } \\
\hline \multicolumn{5}{|l|}{ African catfish } \\
\hline \multicolumn{5}{|l|}{ Clarias gariepinus } \\
\hline Standard fish $1030 \mathrm{~g}$ & 92 & & 31 & Manthey et al. 1988 \\
\hline Experimental fish $646 \mathrm{~g}$ & 90 & & 26 & \\
\hline Female $630 \mathrm{~g}$ & 79 & & 39 & Hoffman et al. 1993 \\
\hline Male $670 \mathrm{~g}$ & 94 & & 47 & \\
\hline \multicolumn{5}{|l|}{ European catfish } \\
\hline \multicolumn{5}{|l|}{ Silurus glanis } \\
\hline $2650 \mathrm{~g}$ & 91 & & 38 & Manthey et al. 1988 \\
\hline $1500-2500 \mathrm{~g}$ & 85 & $65-70$ & $34-43$ & Proteau 1993 \\
\hline \multicolumn{5}{|l|}{ Guyane Silurids } \\
\hline
\end{tabular}


Phenotypic variability in body conformation of catfish has been observed and thought to be related to genetic origin (Dunham et al., 1983, Grober and Van der Bank, 1994). There are large differences between strains of Channel catfish in dress out percentage (Smitherman et al., 1983, Dunham et al., 1983). Within a population, the genetic variabilities of dress out percentage, and of its main component, head percentage, are very low at least in small commercial sizes (El-Ibiary and Joyce, 1978) suggesting few possibilities of direct improvment. The phenotypic correfations of dress out percentage with some indirect characteristics: head length and width, body depth and girth are also low and only body density seems to be a candidate for indirect dress out percentage prediction (Dunham et al, , 1985).

One alternative is to breed another species with high dress out percentages such as blue catfish (Grant and Robinette, 1992), white catfish or their hybrids (Smitherman et al., 1983). In these different populations the genetic variability in dress out percentage at harvest could be predicted partially by the variability in some early body traits (head width and depth and caudal width) (Dunham et al., 1983). It is interesting to note that these early body traits are related to relative growth of the head while at commercial size it is rather adipose tissues that would predict dress out percentage. Such indirect criteria could thus be included in a genetic breeding scheme for dress out percentage improvement.

The next processing step is filleting. Almost $50 \%$ of the catfish market in the USA is devoted to filleting. Due to the curvature of the vertebral axis in Siluriforms, filleting could not be mechanized easily. The filleting yields are low: $30 \%$ compared to other species (salmonids, cyprinids). Some data obtained in European catfish suggest that the filleting yield could amount $40 \%$ (Proteau, 1993; Martin and Petillot, pers. comm.). Differences in filleting percentage would however depend on the removal of abdominal fat and on the way of dressing (Wolsters et al., 1991). There is no data on the variability of this yield and thus on the possibilities of improvement of such yield.

There are no large changes in these yields with aging (Silva-Pacheco, 1987). This is an indication that the different parts of Siluriforms grow allometrically to body weight (Dunham et al., 1985). However, as observed in other species (salmonids, cyprinids), the dressing and filleting yields tend to increase in large fish (Heaton et al., 1973; Proteau, 1993; $\mathrm{Li}$ and Lovell, 1992). Such scaling effect is the consequence of the development of the muscle mass relative to head part and vertebral axis. Furthermore, one limiting factor in filleting suitability is the development of muscle mass in the caudal part of the fish (Proteau, 1993) rather than muscle development in the anterior part. A significant width in that part of the body has to be reached for a efficient flesh removal. Selection for growth rate and even dress out percentage often results in the development of muscle mass just behind the head, and carp provides a clear demonstration of this effect (Fauconneau et al., 1995). It probably resuits from an anteroposterior muscle development gradient not only during embryonic and larval development but also during post-larval growth. Selection has thus to be directed on development of caudal part of fish.

\section{CHARACTERISTICS OF THE FLESH}

The characteristics of the flesh seem to be related to structure and composition.

\section{Structure of flesh and tissue characteristics}

Changes in protein content as well as in lipid content of the flesh result of the relative development of the different tissues which make up the flesh: muscle, connective tissues and adipose tissues. No data is available on tissue development in Siluriforms. It could only be supposed that muscle and adipose tissues have successively or simultaneously a positive growth allometry during a period starting from the post-larval phase up to commercial size as has been observed in other fish (salmonids, cyprinids).

Flesh comprises three different muscle tissues: red superficial, deep white muscle and intermediate pink muscle which differ in their metabolic and contractile properties (Johnston, 1982). These properties are given by the fibre types present in these muscle. Red muscle is composed of slow (slow rate of contraction) oxidative fibre type and white muscle of fast (fast rate of contraction) glycolytic fibre type. Pink muscle consists of an intermediate fibre type (Johnston, 1982). Furthermore, in different fish species, red muscle is a site for lipid storage (Henderson and Torcher, 1987). This has been observed in Channel catfish (Botta, 1974) where the lipid content of red muscle $(21 \%$ fresh weight) is largely higher than that of white muscle (1 to $2 \%$ ).

Although there are few studies on this aspect, the originality of catfish (Ictalurus melas) muscle seems to be related to the complexity of pink muscle and the occurrence of mosaics in white muscle. Pink muscle seems to be composed of two different layers (Mascarello et al., 1986) which are composed of specific fibre types. Catfish white muscle is classified by Rowlerson et al. (1985) as non-mosaic due to its relative homogeneity in terms of size and metabolic and contractile properties of fibre compared to other species. These results have been obtained on young individuals $(20-25 \mathrm{~cm}$ length) in which muscle is rather immature as indicated for instance by the low ratio between the two myosin alkaline light chains of white muscle LC1f/LC3f (Rowlerson et al., 1985) but it could be a general feature of catfish muscle. Another Siluriform (Clarias anguilaris) does not display a wide fibre size distribution (El-Dashlouty et al., 1976). However, a clear mosaic pattern is observed in the white muscle of Heteropneustes fossilis (Urfi and 
Talasera, 1989). Although these differences could be related to species differences, it is also known that different factors and especially nutritional status and season affect fibre type distribution. Further studies are thus certainly required but there is some evidence that white muscle in Siluriforms is rather homogeneous compared to other fish species.

Furthermore, the presence of small fibres in white muscle is generally associated with hyperplasic growth. The small fibres are often different in their metabolic and contractile characteristics from large fibres and they are supposed to be new growing fibres (Urfi and Talasera, 1989). If growth process in catfish is similar to other species, the absence of any mosaic pattern suggests differences in the localization of hyperplasic process, probably at the periphery of the white muscle near the pink muscle (Rowlerson et al., 1985) or even making up one layer of pink muscle. Thus, the main cause of variability of white muscle characteristics, growth rate, would affect only superficially the flesh in catfish when it is affected deeply in other fishes.

Finally the innervation of fibres in cattish white muscle is focal but in other species each fibre is innervated by different motoneurones (Rowlerson et al., 1985). The effect of exercise, another cause of variability in white muscle characteristics, could thus differ in catfish. However no published data supports this assumption.

Although the consequences for flesh quality are not known, the possible homogeneity of deep muscle characteristics and the relative stability of these characteristics during the growth process would certainly explain the general acceptance of catfish flesh. It would be important to validate such a hypothesis in cattish and in different Siluriforms.

The connective tissue is inserted between the myomeres and holds the muscles together (Dunajski, 1979, Bremner, 1992). Connective tissue has been studied in fish of rather large size $(45$ to $65 \mathrm{~cm}$ ). Its thickness seems to be relatively similar amongst the species (Yamaguchi et al, 1976) although such comparisons have not been made on fish of the same age and it is known that thickness of connective tissue should increase with aging (Bremner, 1992). Some early studies suggest that the collagen content in the flesh of catfish: $7 \%$ could be the highest amongst fish species (Sikorski et al., 1984). From the hydroxyproline content of the flesh, it also seems that collagen content of cultured African catfish is lower than that of wild catfish (Hoffman et al., 1993) but this could probably be related to age differences.

The connective tissue of catfish is also strong compared to other fish species and this is also true for the skin of catfish (Yamaguchi et al., 1976). It is probably the consequence of a larger proportion of intermolecular cross-links within collagen. Finally, the susceptibility to thermal denaturation of catfish collagen seems to be higher than that of other species (Yamaguchi et al., 1976; Sikorski et al., 1984) and this is associated with its low proportion of hydroxyproline.

The connective tissues of catfish because of the intrinsic characteristics of collagen therefore ensure the integrity of raw flesh during manipulation. But due to its high thermal sensitivity it could affect other aspects of cooked flesh quality.

Finally adipose tissue has never been studied in itself in Siluriforms. It has generally been studied only in few fish species (Fauconneau et al., 1992; 1995). However, adipose cells can be observed in the flesh between the myomeres and in subcutaneous fat (Fauconneau unpubl.). Lipids in fish can be deposited either in liver, in red muscle or in specific adipose tissues (Henderson and Tocher, 1987). Relative development of visceral fat is not significant in Siluriforms and fatty liver is not observed in these fish. Furthermore, an antero-posterior gradient of lipid contents in fillet or carcass (higher in the caudal part) is observed in many Siluriforms (Jafri, 1973; Shreni and Jafri, 1978; Manthey et al., 1988). By taking into account the similar changes in the proportion of red muscle along the vertebral axis it is suggested that red muscle is responsible for such a gradient.

\section{Chemical composition}

General changes in composition during aging are a stabilization of protein content, an increase in lipid content and a concomitant decrease in water content (Degani, 1983). There are no information available on changes in protein composition (protein fractions and amino acid composition) during aging but this variability is generally not very significant in fish (Fauconneau et al., 1995). The amino acid composition of catfish flesh is not very informative even for the nutritive value of the flesh, as they are very similar from one species to another species (Manthey et al., 1988; Hoffman et al., 1993; Clement and Lovell, 1994) (fig. 1).

The lipid content in the flesh is low in different catfish species. Recent data always gives however more than $6 \%$ lipid (\% fresh weight) in the flesh (table 2) and belly fat as well as high lipid content in the flesh have been reported (Sheperd and Bromage, 1988). Thus the control of flesh lipid content could be in the future an important aim for quality studies both to ensure a minimum amount of lipid (development of aroma and pigmentation) and to avoid fatty fish. Different factors affect lipid content in Siluriforms as in other fish: body weight, season, feeding, dietary protein and dietary lipid (table 2). Large differences in lipid content between strains (Erickson, 1993) and hybrids (Smitherman et al., 1983) are reported. There is a genetic variability in lipid content of the flesh but when measured directly it is rather low and its heritability is lower than 0.1 (El-ltiary and Joyce, 1978) but this data has to be confirmed with current lipid content observed in catfish. Furthermore, 


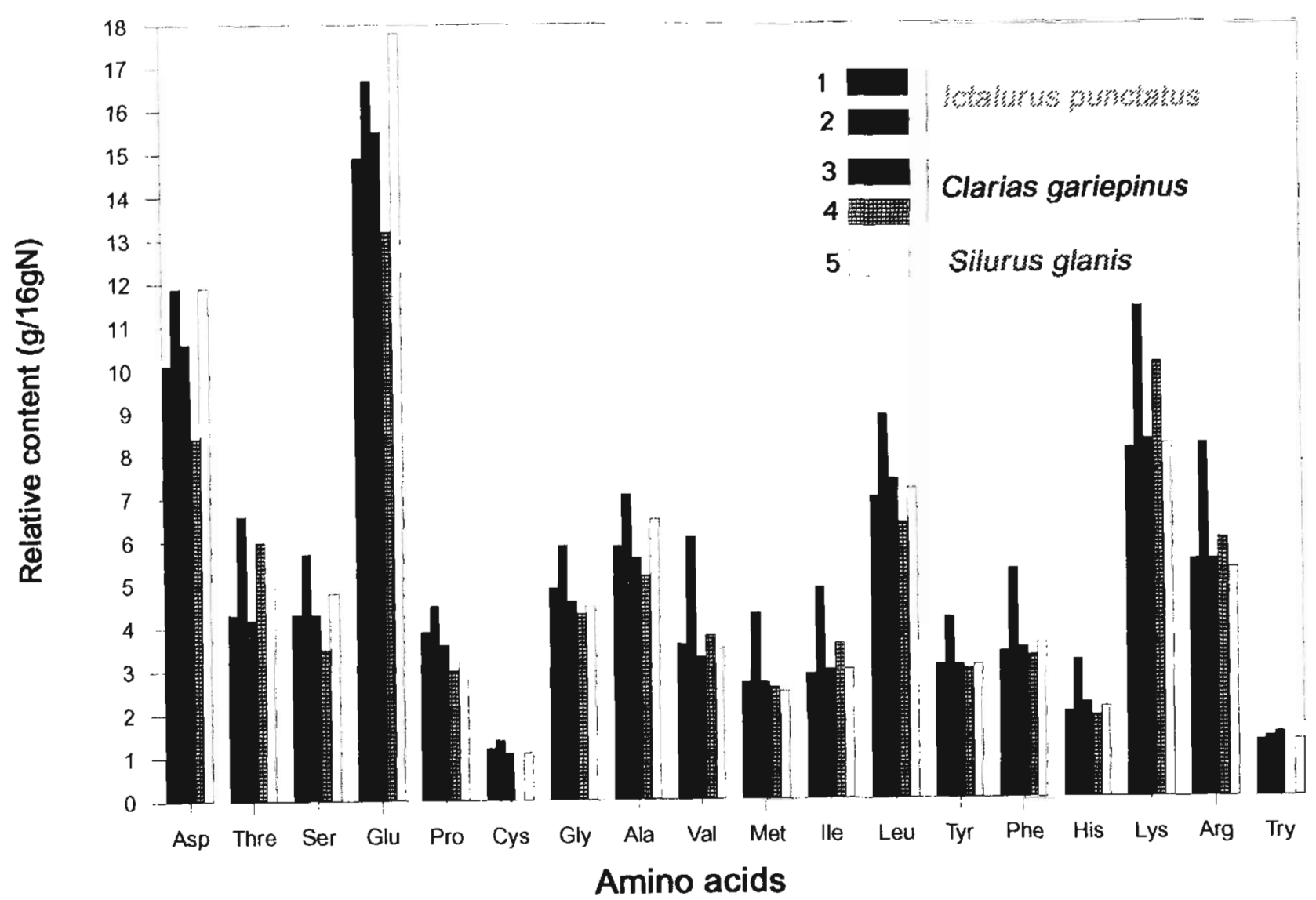

Figure 1. - Amino acid composition of total protein in Siluriforms flesh (from (1, 3, 5) Manthey et al, 1988; (4) Hoffman et al., 1992; (2) Clement and Lovell, 1994].

selection for growth rate of catfish is associated with lower lipid content in the flesh (Tidwell, 1988) and this is a rather positive point.

The lipid content in fish flesh is an important quality factor but the fatty acid composition is also important especially for physical stability (melting point of lipid) and for lipid susceptibility to oxidation which affects both aroma and potential rancidity.

The flesh of farmed Channel catfish and African catfish comprises less than $1 \%$ phospholipids (Mitchell, 1987; Akoh and Hearnsberger, 1993) which contains over $40 \%$ polyunsaturated fatty acids (Erickson, 1992). These phospholipids contain roughly the same content of $w 3$ and w6 fatty acids (w3/w6 ratio: 0.7) (Erickson, 1992). The phospholipid content and composition show the same pattern in wild Channel catfish (Chanmugam et al., 1986) and in marine catfish (Choi et al., 1985; Smith et al., 1990) except for the content of w3 fatly acids which are higher in marine catfish.

The main lipids are neutral lipids with a composition which mainly reflects that of the diet. They contain high levels: more than $49 \%$, of monounsaturated fatty acids (fig. 2) (Tidwell and Robinette, 1990, Erickson 1992, Akoh and Hearnsberger, 1993) and their content of $w 3$ fatty acids is low ( $w 3 / w 6$ ratio: 0.1 to 0.2 ) (fig. 3). The proportion of monounsaturated fatty acid increases with body weight (Tidwell and Robinette, 1990).

If fatty acid composition of neutral lipids is mainly controlled by diet composition, other factors can slightly modify this composition. Extrinsic factors such as season (Mitchell, 1986) and intrinsic factors such as aging (Tidwell and Robinette, 1990) and genetic origin (Erickson, 1992) have thus to be taken into account.

Lipids are highly susceptible to oxidation (Erickson, 1992) because of their high PUFA content. The presence of a natural antioxidant such as alphatocopherol within the flesh could partially prevent the oxidation process. The tocopherol content could be controlled by the diet (Gatlin et al., 1992).

Finally, the pigmentation of fish flesh is an interesting aspect. The colour of Siluriforms is rather subtle compared to that of salmonids and cyprinids. The grey colour of the flesh and its distribution pattern is rated rather positively by traditional catfish consumers. Yellow/beige/pale pink colours are also found in the flesh of other catfish (fig. 4a). This specific colour spectrum and homogeneity could be reproduced in farmed catfish 
Table 2. - Lipid content (\% fresh weigth) in carcass or fillet of commercial size farmed silurids.

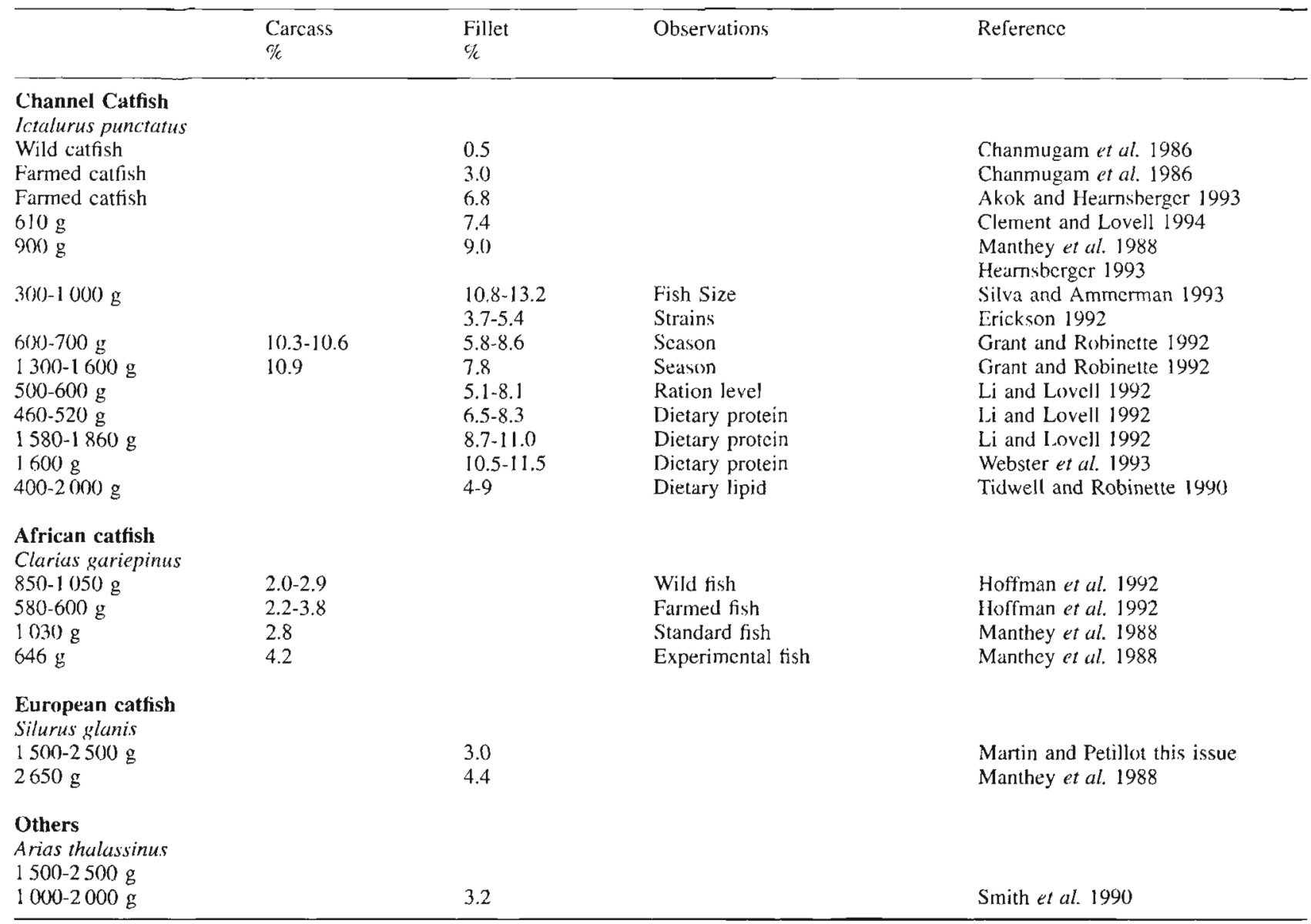

by dietary supplementation with carotenoid pigments (Smitherman et al., 1988). For a more neutral aspect and for the development of new processes, however a white flesh could be required (Heaton et al., 1973). For that purpose, the rearing of albinos catfish has been developed and their colour is very close to that of white marine fish (Paredes and Baker, 1987). In this fish but also in European catfish cooking has little effect on colour $(f i g .4 b)$, although cooked flesh is more yellowish than raw flesh (Choudrhy, 1977).

\section{QUALITY ASSESSMENT OF THE FLESH}

\section{Physical properties of fish flesh}

The water holding capacity of fish flesh is generally high compared to meat (Fauconneau et al., 1995). In European catfish, the water holding capacity is lower than that of salmonids but close to that of cyprinids (table 3) (Laroche and Marcel unpubl.). It also seems to be lower in Channel catfish than in marine fish (Paredes and Baker, 1987). Such characteristics are generally associated with a greater juiciness of the flesh (Paredes and Baker, 1997).

However, the cooking yield is low and close to that of young, pan size rainbow trout indicating that characteristics of actomyosin in terms of thermogelification and water-holding capacity are rather low. Water-holding capacity seems however to increase slightly with age (Heaton et al., 1973) and it could be interesting to relate such changes to muscle growth process.

The mechanical behaviour of Siluriforms flesh is very specific. The tenderness assessed by maximum shear strength or resistance to deformation is higher in raw flesh than that observed in salmonids but similar or lower than that observed in cyprinids (table 3, fig. 5) and marine fish (Paredes and Baker, 1987). This behaviour could be related to the higher content and strength of collagen in catfish flesh. Cooking has no or little effect on the flesh texture (Bogess et al., 1973; Paredes and Baker, 1987; Laroche, unpubl.). This is rather surprising as in other species, cooking either increases (salmonids) or decreases (cyprinids) mechanical strength (table 3). 


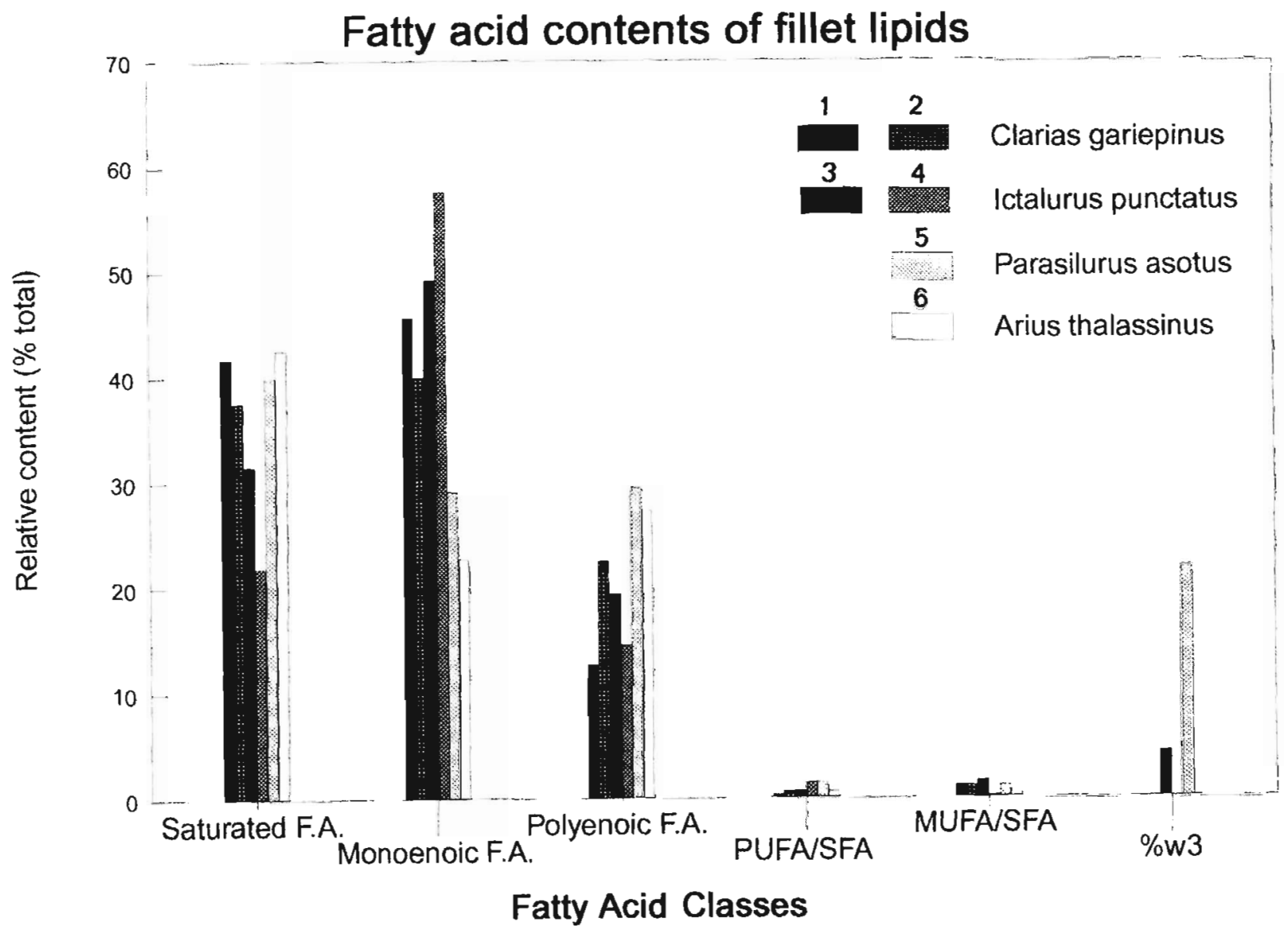

Figure 2. - Fatty acid classes in the Hesh of different Siluriforms (from (5) Choi et al., 1985; (2) Manthey et al., 1988; (6) Smith et al., 1990; (4) Erickson, 1992: (1) Hoffman et al., 1993; Akoh and Hcamsberger, 1993!.

The changes of Siluriforms flesh due to cooking are thus intermediate within what is gencrally observed in freshwater fish. It could be emphasized that this is the result both of low thermogelification potential of actomyosin and high susceptibility of collagen to thermal denaturation.

\section{Sensory evaluation and flavor}

Whole fresh fish is the main product of the traditional market. Very little is known conceming the criteria of assessment of whole fish quality (aspect, odour) but consumers also cat other freshwater fish like cyprinids in Europe, tilapia in Africa, milktish in Asia and different pond fish in central USA. Siluriforms are also often associated with sport fishing and these consumers eat fresh fish. There are therefore able to assess fresh fish quality, know how to cook whole fish and appreciate the subtle tasting of catfish.

Generally the sensory evaluation of the quality of fish flesh is not very easy. In farmed fish the odour and flavor are rather subtle, texture is rather soft and juiciness is poor as compared to meat. These characteristics are partially the consequences of the high water holding capacity of fish flesh. Trained panels and specific criteria for each species analysed are thus required. Good sensory analysis could be realized for colour, odour related to freshness, texture and juiciness criteria and this has been used for Channel catfish (Heaton et al., 1973, Botta, 1974, Gibson et al., 1977; Manthey et al., 1988; Silva and Ammerman, 1993), African catfish (Manthey et al., 1988), European catfish (Manthey et al., 1988) and marine catfish (Poulter et al., 1981, Paredes and Baker 1987). Compared to other fish, Siluriforms are generally tougher and have high juiciness. But flavor and aroma are rather mild or neutral compared to other cultured fish or to marine fish. Catfish consumers seem to prefer a mild tasting rather than a strong tasting flavor (Sheperd and Bromage, 1988). Few changes with aging have been observed by sensory evaluation (Heaton et al., 1973).

Two important aspects of sensory evaluation have been especially studied in Channel catfish: the fine description of aroma and flavor and the occurrence of off-flavors. It provides data which is complementary 


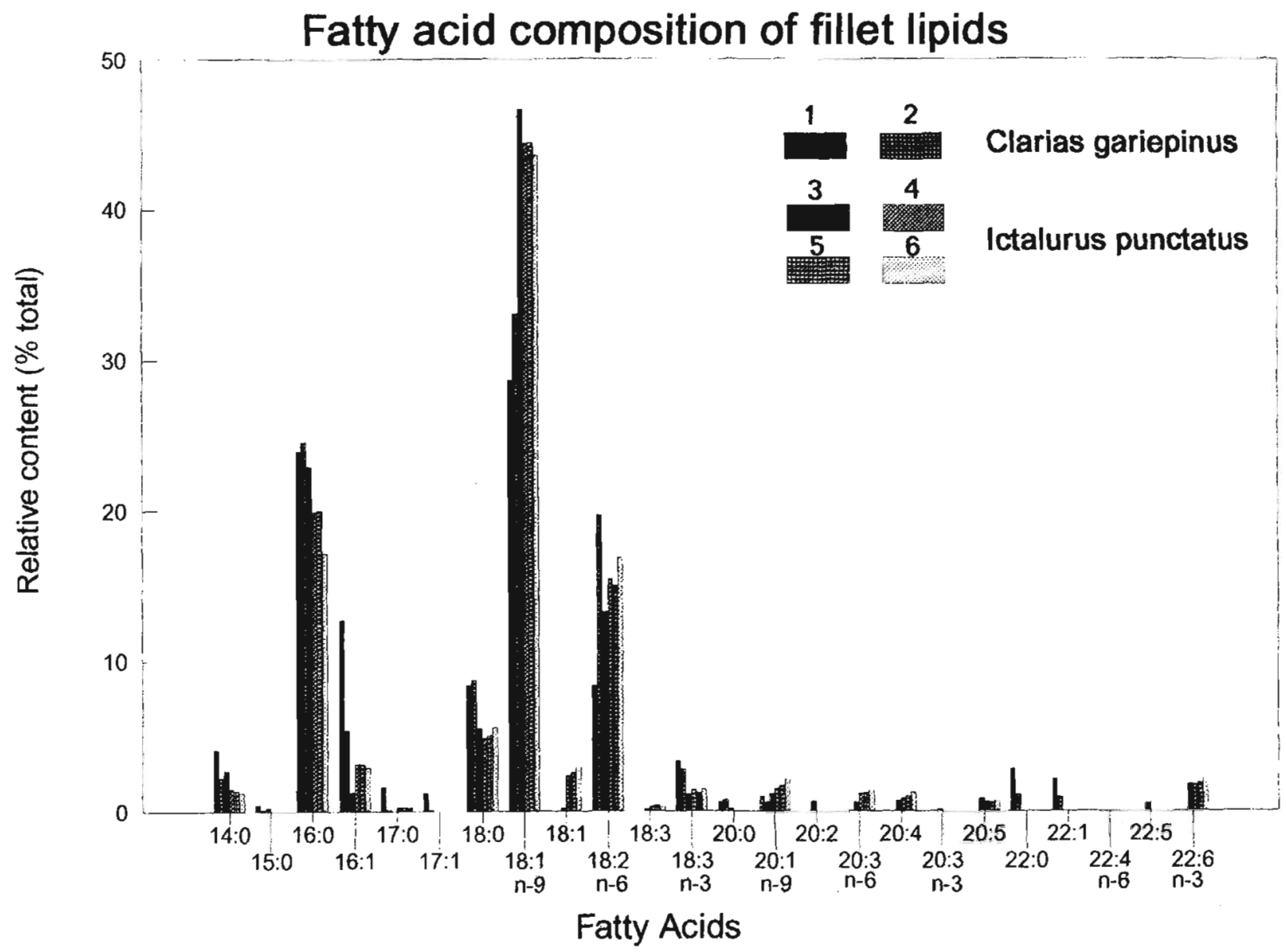

Figure 3. - Fatty acid composition of total lipid in Siluriforms flesh [from (2, 6) Manthey et al., 1988; (5) Erickson, 1992, (1) Hoffiman ef al., 1993; (2) Akoh and Hearnsberger, 1993; (4) Clement and Lovell, 1994J.

to the aroma analysis which has been developed in other species such as salmonids (Josephson, 1990).

The descriptors generally used to describe the flavor of Channel catfish are reported in a lexicon (Johnsen et al., 1987). For aroma, these descriptors are for instance: nutty, chickeny, grainy, fat complex, putrid, rotten plants, cardboard, painty, musty/woody, bluegreen. Thus, there are related either to "on-flavors" and desirable flavors, or to rancidity, degradative processes and off-flavors. For taste, the descriptors are: sweet and salty.

This standardized sensory evaluation has been applied to study the effect of diet on the specific fiavor of Channel catfish (Johnsen, 1989; Johnsen and Dupree, 1991; Webster et al., 1993) combined or not with a method of sample preparation (Johnsen and Kelly, 1990). On the basis of desirable flavors, trained panelists are able to discriminate between diets containing different feed ingredients. The few significant differences observed are not related to the categories of feed ingredients: fats and oil, fish meal and animal by-products and grains. The authors concluded that the desirable flavors of catfish are related to the fish itself rather than to diet. However such studies have been conducted on small Channel catfish $(150 \mathrm{~g})$ which has a relatively low lipid content.

Furthermore, it seems that composition of the lipid in the diet could significantly affect either positively or negatively catfish flavor (Gibson et al., 1976; Dupree et al., 1979) but other descriptors than those related to rancidity have to be implemented. The relationship between instrumental aroma analysis and sensory evaluation has still to be made for catfish in order to make a link between some of the flavors descriptors and precursor compounds present in the flesh (Josephson, 1990). It is for instance important to know if w6 polyunsaturated fatty acid which dominates in catfish flesh is equally susceptible as w3 PUFA to lipoxygenase attack then to autooxidation (Hsieh and Kinsella, 1989). The products of such oxidation processes are volatile organic compounds which are responsible for on-flavor (generally plant aroma). It is not certain that these compounds are related to all specific flavors described 

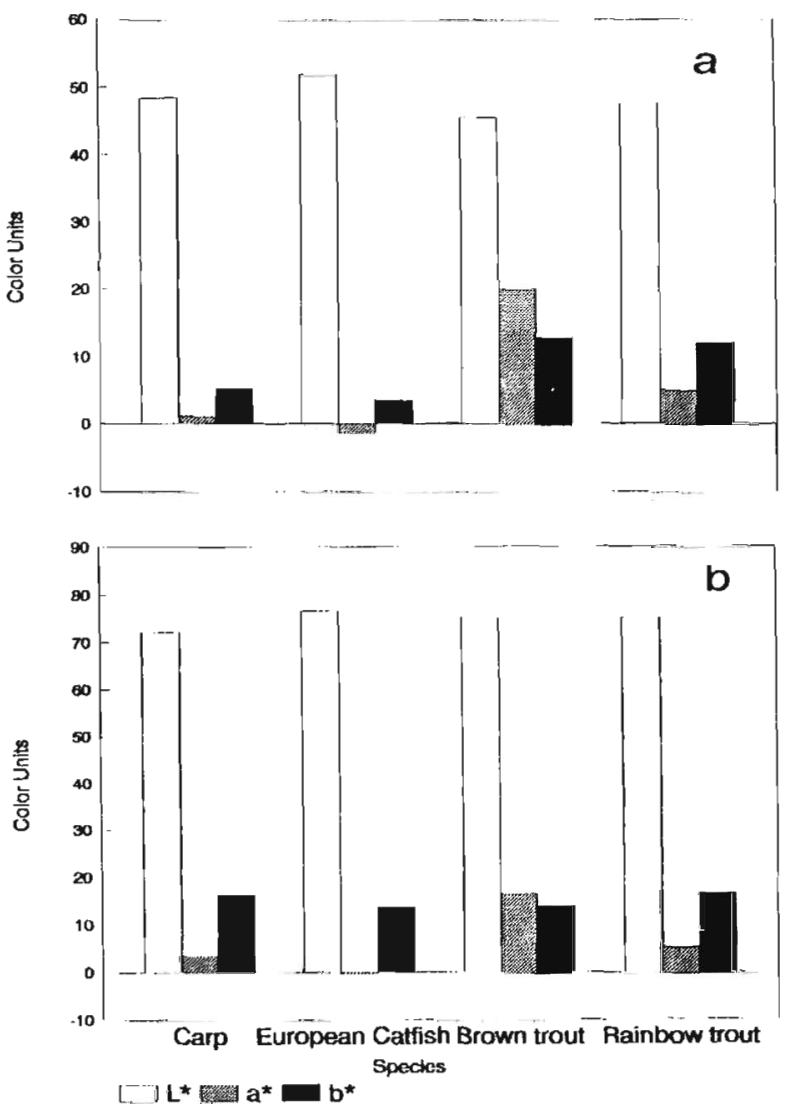

Figure 4. - Instrumental measurement of $(a)$ raw and $(b)$ cooked Hesh colour: $L^{*}$ brigthness, a* red index, $b^{*}$ yellow index in different fish species, see tabie 3 for more details.

for catfish (nutty, chickeny, grainy, etc.). Some of these flavors could be related more to the effect of thermal processing on protein compounds than to lipid decomposition processes (Josephson, 1990).

The occurrence of off-flavor is an important aspect for all pond fish and especially for Siluriforms whose taste and flavor are rather subtle. The products responsible for the main off-flavors such as earthy/musty and blue-green (Lovell, 1983) are respectively identified as geosmin and methyl-isoborneol (MIB). These two compounds are detected at very low levels by consumers $(0.01 \mathrm{ppb}$ ) (Spanier and Johnsen, 1992). The uptake of these compounds by fish is very rapid (a few hours when added in the environment) but the clearance when fish are transferred into clear water is very much longer ( 2 to 3 weeks) (Lovell and Sackey, 1973; Spanier and Johnsen, 1992). They are produced by microorganisms generally found in the ponds or in the tanks: an actinomycete (Streptomyces) and a blue green algae (Oscillatoria) (Smith, 1988; Martin et al., 1991). Their production largely increases during summer (Amstrong et al., 1986). When one of these microorganisms (Oscillataria) dominates amongst the
Table 3. - Water holding capacity and texture of European catfish Silurus glanis compared with brown trout (Salmo trutta) and carp (Cyprinus carpio L.) and pan size rainbow trout (Oncorhynchus mykiss).

\begin{tabular}{|c|c|c|c|c|}
\hline & Carp & Catfish & $\begin{array}{l}\text { Brown } \\
\text { trout }\end{array}$ & $\begin{array}{l}\text { Rainbow } \\
\text { trout }\end{array}$ \\
\hline Body weight ( $\mathrm{kg}$ ) & $1.5-1.7$ & 1.5 & 3.0 & $0.25-0.3$ \\
\hline \multicolumn{5}{|l|}{ Raw flesh } \\
\hline $\begin{array}{l}\text { Water-Holding capacity } \\
(\%) \\
\text { Maximum strength }\end{array}$ & $56-69$ & 68 & 77 & 66 \\
\hline (N) Kramer Press & $817-1082$ & 1275 & & 328 \\
\hline $\begin{array}{l}\text { Maximum strength } \\
\text { (N) Comp test }\end{array}$ & $13-15$ & 8.8 & 8.4 & \\
\hline Cauchy modulus & 7.8 & 3.5 & 9.1 & \\
\hline Cooking yield (\%) & $82-85$ & 77 & 88 & 77 \\
\hline \multicolumn{5}{|l|}{ Cooked flesh } \\
\hline Water-Holding Capacity & & & & \\
\hline $\begin{array}{l}\text { \% cooked flesh } \\
\text { Maximum strength }\end{array}$ & 65 & 69 & 75 & 78 \\
\hline (N) Comp Test & $3.5-3.7$ & 8.6 & 31.3 & \\
\hline Cauchy modulus & $1.8-2.0$ & 3.4 & 13.0 & \\
\hline
\end{tabular}

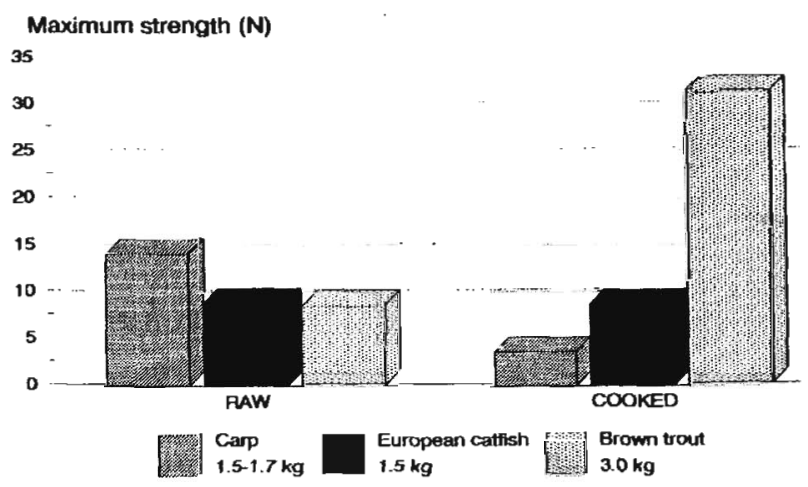

Figure 5. - Maximum strength (in Newton) of the flesh in a compression test in different fish species.

phytoplankton population, there is an increased level of MIB in the ponds (Lorio et al., 1992) and off-flavors appeared within one week in fish.

In order to control off-flavors, regular phytoplankton population analysis could be used to predict the appearance of the two compounds. The use of herbicides to control the algae population itself is not effective firstly because they are not selective and secondly because the off-flavor compounds present in the microorganisms are released into the environment when it dies (Smith, 1988). Other algae population control methods seem to have failed (Smith, 1988). However, the specific control of actinomycete development seems possible by the use of competitive geosmin synthesis inhibitors (Dionigi et al., 1990, 1991). 
One interesting point is to learn more about the physiology of these microorganisms and especially about the role of these compounds (Spanier and Johnsen, 1992). The production of MIB and geosmin could play a role in detoxification (mixed function oxidase) processes (Dionigi et al., 1991; Spanier and Johnsen, 1992) within these microorganisms. This data suggests that microorganisms producing off-flavors are subject to stress and this could be related to the fact that off-flavors are often observed in a eutrophic environment. The manipulation of phytoplankton population by controlling the production of these compounds seems to be possible.

Furthermore, due to their structure, these compounds, when present in fish, could be metabolized through cytochrome $\mathrm{P} 450$ pathways. If MIB is administered to fish, there are no changes in cytochrome P450 content but significant changes in isozyme patterns in liver and kidney (Shlenk, 1994). This suggests not only that MIB could be metabolized by fish, the metabolites of MIB having no off-flavor effect (Martin et al., 1988; Mills et al., 1993) but also that the detoxification processes of fish are probably affected by MIB or geosmin impregnation.

\section{STORAGE AND PROCESSING}

The characteristics described in the previous chapter are those of fresh fish. They could be altered or enhanced during storage or further processing.

\section{Slaughtering method}

Little attention has been paid to the method of slaughtering. Classic methods used in catfish (electrical narcosis) but also ice immobilization cause rapid alteration and poor flesh quality especially if fish are not bled. Other methods have been tested, using $\mathrm{CO}_{2}$ and bleeding. These methods give better results in terms of colour, flavor and texture (Bogess $e t a l$, 1973).

\section{Postmortem changes}

The flesh of different catfish species when stored on ice are subjected to different alteration processes (enzymatic and microbial) as observed in all fish (Fauconneau et al., 1995 for description of the main steps). In farmed fish, microbial alteration could be controlled and the shelf life of catfish flesh is rather good. Freshness or spoilage of flesh stored in different conditions have been studied (Poulter et al., 1981; Reed et al., 1983; Manthey et al., 1988; Bhattacharyya and Chaudhuri, 1990) to determine the shelf life of different Siluriform species and to develop freshness descriptors. Different lipid oxidation indices have also been tested (Smith et al., 1990). Shelf life is dramatically affected by high temperature storage (Bhattacharyya and Chadhuri, 1990).
It is however more interesting to pay attention to other post-mortem changes. The rigor process has been observed in catfish muscle fibres (Clarias anguilaris). An increase in fibre diameter and a decrease in sarcomere length have been described (El-Dashlouty et al., 1976). Rigor onset is a very critical point as in order to avoid gaping phenomena, fish which are processed has to be manipulated before rigor appears. Rigor onset is affected by storage temperature and also by slaughter method. However rigor onset time could not be a critical point for catfish due to the strength of its connective lissue.

At the same time there is a mechanical and enzymatic degradation of different extracellular and intracellular components leading to a softening of the flesh. This have been observed in European catfish (Manthey et al., 1988).

\section{Freezing}

During frecsing, there is a gradual denaturation of protein, leading to a decrease in water-holding capacity (Fauconneau et al., 1995). Freezing also appears to improve flesh firmness (Bogess et al., 1973; Woodruff, 1988) and this is a rather positive sensory characteristics for Channel and European catfish (Gibson et al., 1977; Martin and Petillot, pers. comm.). Lipid denaturation is also obscrved during freezing. Polyunsaturated fatty acids from phospholipids are degraded and free fatty acids increase. Peroxide value also increases during freezing (Srikar et al., 1989) but that is not always the case (Silva and Ammerman, 1993). Catfish can be preserved during long periods of time $\left(300 \mathrm{~d}\right.$ and more) by freezing $\left(-18^{\circ}\right.$ to $\left.-20^{\circ} \mathrm{C}\right)$ (Gibson et al., 1977; Woodruff, 1988; Srikar et al., 1989; Silva and Ammerman, 1993). However rancid odors and flavors have been detected in fillets of catfish after 2 months of frozen storage $\left(-20^{\circ} \mathrm{C}\right)$ under commercial conditions (Freeman and Shannon, 1994).

\section{Processing}

The low acceptability of catfish flesh as well as intrinsic characteristics such as holding capacity and texture of the fillet explain why different processes have been applied to catfish (table 4).

Traditional processes (drying, salting, smoking) are used to preserve fish or fish fillets (table 4). Improvement of these traditional processes have been proposed especially to increase shelf life or to avoid toxic compounds induced by smoking (Faturoti, 1983, 1984, Afoul et al., 1986).

Smoking of Channel catfish in controlled condition gives a product with characteristics close to smoked haddock or chubs. Catfish could therefore be a substitute for these traditional products (Bogess et al., 1973). It has also been applied to European catfish and African catfish (Manthey et al., 1988; Dilemma, 1992) as well as to marine catfish (Turned, 1977). However, 
Table 4. - Processing of catfish und sensory evaluation of acceptability of end-product.

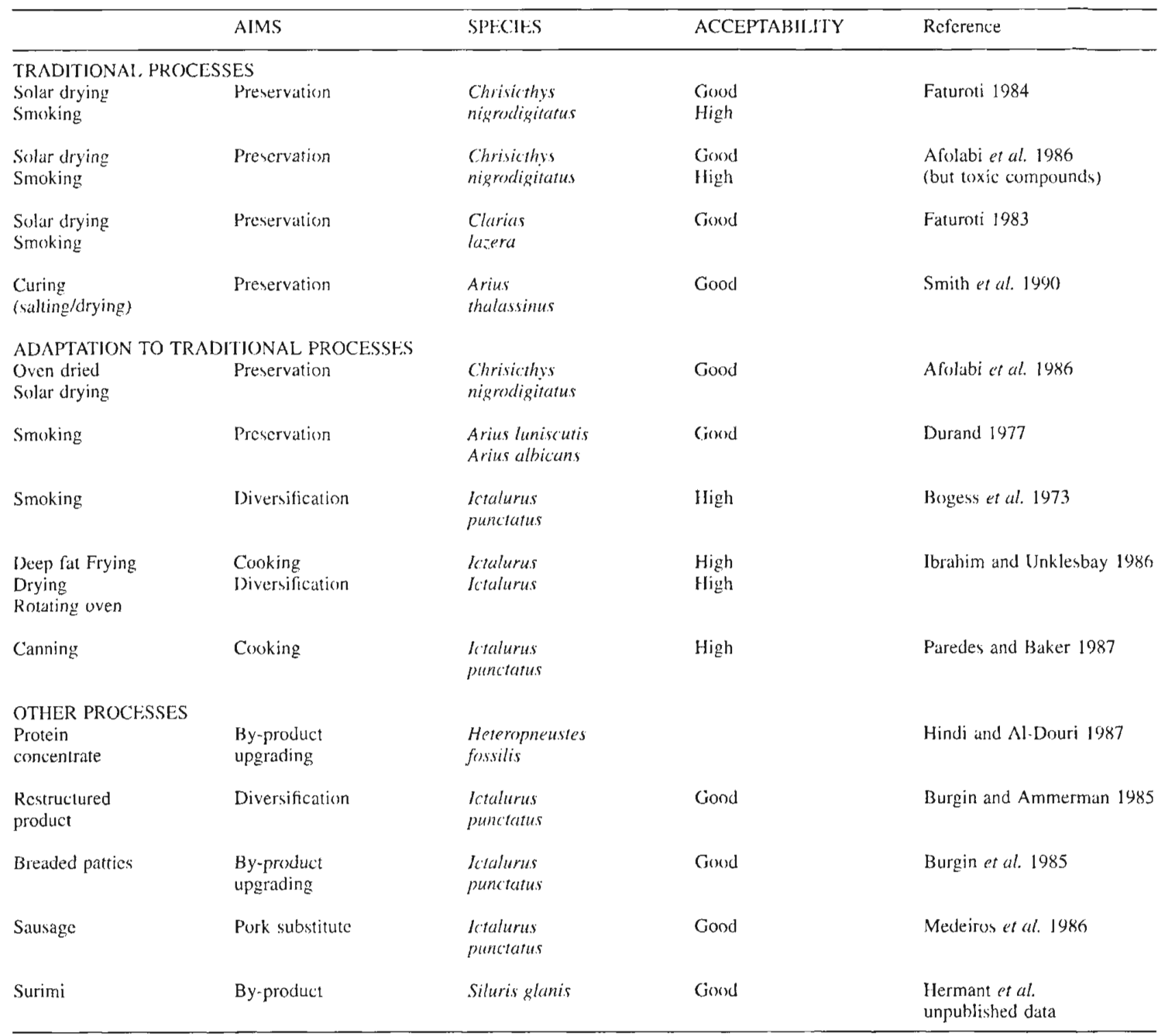

although hot smoking is not really justificd as the lipid content of the flesh is not high, smoking is carried out at relatively high temperature (more than $80^{\circ} \mathrm{C}$ ).

The traditional way to prepare catfish fillets, either fresh or frozen is deep-fat frying (Ibrahim and Unklesbay, 1986; Manthey ef al., 1988) or canning. The subtle catfish aroma is certainly altered by this process as well as the lipid composition, due to supplementary fat gain by the product.

Other processing methods have been tested on catfish using other cooking processes. Minced or washed flesh have been developed to produce steaks, reconstructed products, sausages or nuggets (table 4). The aims of such processes are to obtain substitutes for other animal products. In every case, catfish flesh demonstrated a great ability 10 processing. This is due to its rather neutral characteristics and its homogeneity but probably also to the suitability of fish actomyosin for thermogelification. The effects of certains factors such as reconstructed product mixing time (Abide and Silva, 1990), the addition of polyphosphate or salt in patties (Burgin et al., 1985), the effect of salt in sausage (Medeiros et al., 1986) on the quality of the final product have been assessed. The changes in terms of firmness or toughness suggest the involvement of actomyosine properties. Furthermore, there have been few studies of catfish pulp valorization probably because of the low thermogelification ability of actomyosine compared to other fish. 


\section{CONCLUSION}

Although catfish farming is well developed, there is a lack of data concerning their intrinsic characteristics relevant for quality. For instance, little is known concerning the variability of processing yield (dressing and filleting) and more particularly genetic variability and correlation with body conformation traits. Less is known of flesh tissues and protein components. Thus basic knowledge of the characteristics of the flesh involved in the great stability of the flesh and its suitability for processing is lacking. The flesh itself is rather neutral and flavor is mild making it therefore very acceptable if off-flavor compounds are not present. Furthermore thanks to the relative resistance of the flesh during processing or freezing and its neutral flavor, catfish flesh could be processed as a substitute for other animal products.

\section{REFERENCES}

Abide G. P., J. O. Hearnsberger, J. L. Silva 1990. Initial fish state and mixing time effects in textural characteristics of a restructured catfish product. J. Food Sci. 55, 1747-1748.

Akoh C. C., J. O. Hearnsberger 1993. Fatty acid profiles of farm-raised catfish fillet: total lipids and phospholipid classes. J. Aquat. Food Prod. Technol. 1, 43-55.

Amstrong M. S., C. E. Boyd, R. T. Lovell 1986. Environmental factors affecting flavor of channel catfishy from production ponds. Progress. Fish Cult. 48, 113-119.

Bhattacharyya S. K., D. R. Chaudhuri 1990. Studies on storage characteristics of Clarius batrachus at different temperatures. Fish Technol. 27, 127-129.

Bogess T. S. Jr, E. K. Heaton, L. R, Beuchat 1973. A procedure for processing smoked channel catfish (Ictalurus punctatus). J. Milk Food Technol. 36, 469-473.

Bogess T. S., E. K. Heaton, A. L. Shewfelt, D. W. Parwin 1973. Techniques for stunning channel catfish and their effect on quality. J. Food Sci. 38, 1190-1193.

Bondari K. 1983. Response to bidirectional selection for body weight in channel catfish. Aquaculture 33, 73-81.

Borresen T. 1992. Quality aspects of wild and reared fish. In: Quality assurance in the fish industry. H. H. Huss eds. Elsevier Publishers 1-17.

Botta J, R. 1974. Chemical and organoleptic quality changes of frozen stored and canned channel catfish. PhD Thesis, Louisiana State University.

Burgin J. M., R. W. Rogers, G. R. Ammerman 1985. Effects of salt and tripolyphosphate on some quality characteristics of breaded patties made from catfish trimmings. J. Food Sci. 50, 1598-1601.

Chanmugam P., M. Boudreau, C. Jefcoat, D. H. Hwang 1986. Lipid composition differs in wild and cultured fish and shellfish. Louisiana Agric. 29, 8-9.

Choi J. H., S. H. Park, J. I. Ro, J. H. Pyeun, S. N. Choe 1985. Distribution of lipid components in various tissues of catfish parasilurus asotus. Korean J, Food Sci. Technol. 17, 15-21.

Choudry M. S. 1977. Effect of thermal processing, size and storage on the carotenoid pigment content and other quality factors of channel cattish. PhD thesis, Mississippi State University, $69 \mathrm{p}$.

Chrisman C. L., W. R. Wolters, G. S. Libey 1983. Triploidy in channel catfish. J. World. Maricult. Soc: 14, 279-293.

Clement S., R. T. Lovell 1994, Comparison of processing yield and nutrient composition of cultured Nile tilapia (Oreochromis niloticus) and channel catfish (Ictalurus punctatus). Aquaculture 119, 299-310.

Copin Y., M. Oswald 1992. Orientation des techniques d'élevage de la pisciculture artisanale dans le centreouest de la Côte d'Ivoire. In: Production, Environment and Quality. G. Barnabé, P. Kestemont eds. Eur. Aquac. Soc., Spec. Publ. 18, 407-417.

Degani G. 1988. Body composition of African catfish (Clarias gariepinus) at different ages. Isr. J. Aquac. Bamidgeh 40, $118-121$.

Dionigi C. P., D. A. Greene, D. F. Millie, P. B. Johnsen 1990. Mixed function oxidase inhibitors affect production of the off-llavor microbial metabolite geosmin. Pest. Biochem. Physiol. 38, 76-80.

Dionigi C. P., D. F. Millie, P. B. Johnsen 1991. Effects of farnesol and the off-flavor derivative geosmin. Appl. Environ. Microbiol. 57, 3429-3432.

Dunham R. A., M. Benchakan, R. O. Smitherman, J. A. Chappell 1983. Correlations among morphometric traits of fingerling catfishes and the relationship to dressing percentage at harvest. J. World Maricult. Soc: 14, 668-675.

Dunham R. A., J. A. Joyce, K. Bondari, S. P. Malvelstuto 1985. Evaluation of body conformation, composition and density as traits for indirect selection for dress-out percentage of channel catfish. Progress. Fish Cult. 47, 169-175.

Dunham R. A., R. O. Smitherman 1983. Response to selection and realized heritability for body weight in three strains of channel catfish, Ictalurus punctatus, grown in earthen ponds. Aquaculture 33, 89-96.

Dunham R. A., R. O. Smitherman, R. K. Goodman, P. Kem 1986. Comparison of strains, crossbreeds and hybrids of channel catfish for vulnerability to angling. Aquaculture 57, 193-201.

Dunajski E. 1979. Texture of fish muscle. J. Text. Stud. 10, $301-318$.

Dupree H. D., E. J. Gauglitz, A. S. Hall, C. R. Houle 1979. Effects of dietary lipids on the growth and acceptability (flavor) of channel catfish (Ictalurus punctatus). In: Fishfish nutrition and fishfeed technology. J. E. Halver, K. Tiews eds. Vol II, Heenemann Berlin, 87-103.

Durand H. 1977. Preservation by smoking of some Guyanese lagoon fish (Siluridae) In: Handling, processing and marketing of tropical fish. Tropical Products Institute, U.K. 327-329.

El-Dahouty M. S., N. E. Hafiz, T. M. Dessouki 1976. Post mortem changes of catfish. Agric. Res. Rev. 54, 153-162.

El-Ibiary H. M., J. A. Joyce 1978. Heritability of body size, dressing weight and lipid content in channel catfish. J. Anim. Sci. 47, 82-88.

Erickson M. C. 1992. Variation of lipid and tocopherol composition in three strains of channel catfish (Ictalurus punctatus). J. Sci. Food Agric. 59, 529-536.

Faturoti E. O. 1983. Biochemical evaluation of the nutritive value of differently processed fish (Clarias lazera). Nutr. Rep. Int. 27, 1059-1069. 
Faturoti E. O. 1984. Biochemical evaluation of the nutritive quality of differently processed fish (Chrisichthys nigrodigitatus). Nutr. Rep. Int. 30, 1327-1335.

Fauconneau B., S. André, J. Chmaitilly, M. Cardinal, J. P. Dumont, M. Laroche, J. L. Vallet 1992. Characteristics of the flesh of rainbow trout (Oncorhinchus mikiss). I cellular and chemical components. Sci. Alim. 13, 173-187.

Fauconneau B.. H. Alami-Durante, M. Jaroche. J. Marcel, D. Vallot 1995. Cirowth and meat quality relations in carp. Aquaculure 129, 265-297.

Freeman 1). W., C. W. Shannon 1994. Rancidity in froeen catfish fillcts as influenced by antioxydant injection and storagc. J. Aquat. Food Prod. Tech. 3, 65-76.

Gatlin D. M. III, S. C. Bai, M. C. Erickson 1992. Effects of dictary vitamin $\mathrm{E}$ and synthetic antioxydants on composition and storage quality of channcl catfish, Ictalurus puncsatus. Aquaculture 106, 323-332.

Gibson T. A., R. E. Worthington, E. K. Heaton, L. R. Beuchat 1977. Quality evaluation of frozen stored channel catfish grown by tank culture: effects of dictary fat, freezing method and storage temperature. $J$. Fond Sci. 42, 352-354.

Gibson T. A., R. E. Worthington 1977. I.ipid changes in frozen stored channel catfish grown by tank culture: effects of dietary fat, freczing method and storage temperature. J. Food Sci. 42, 35.5-358.

Grant J. C., H. R. Robinette 1992. Commercial important traits of bluc and channel catfish as related to second summer, winter and third summer growth. Aquaculture 105, 37-45.

Grober J. P., F. H. Van Der Bank 1994. Allozyme polymophism and phenotypic variation in African callish (Clarias gariepinus). Comp. Biochem. Physiol. 107B, $111-116$.

Haard N. F. 1992. Control of chemical composition and food quality attributes of cultured fish. Food Res. Int. 25, 289-307.

Heaton E. K., T. S. Boggess, R. E Worthington 1973. Quality comparisons of albino and regular (gray) channel catfish. J. Food Sci. 38, 1194-1196.

Hindi M. J., S. K. Al-Douri S. K. 1987. Processing of fish protein concentrate from Hoterometuste.s fossilis. Iraci J. Agric. Sci. 5, 31-39.

Hoflman L. C., N. H. Casey, J. F. Prinsloo 1992. Carcass yield and filtet chemical composition of wild and larmed African sharptooth Clarias gariepinus. In: Production, environment and quality. G. Jarnabé, P. Kestemont eds. Eur. Aquac. Soc., Spec. Puhl. 18, 422-432.

Hsieh R. J., J. E. Kinsella 1989. Lipoxygenase generation of specific volatile flavor carbonyl compounds in fish tissues. J. Agric. Food Chem. 37, 279-286.

Ibrahim N., N. F. Unklesbay 1986. Comparison of heat processing by rolating hot air and deep fat frying: effect on selected nutrient content and protein quality of cattish. J. Can. Dietetic. Assoc. 47, 26-31.

Jafri A. K, 1973. Fat and water distribution patterns in the flesh of the common catfish Wallago attu (B1. and Schn.). Fish. Technol. 10, 138-141.

Jaramillo F. Jr, S. C. Bai, B. R. Murphy. D. M. Gatlin III 1994. Application of electrical conductivity for non destructive measurement of channel catfish. Irtalurus punctatus, body composition. Aquat. Living Resour. 7. 87-91.
Johnsen P. B., G. V. Civille, J. R. Vercellotti 1987. A lexicon of pond-raised catfish flavor descriptors. J. Sens. Stud. 2, 85-91.

Johnsen P. B. 1989. Factors influencing the flavor quality of farm-raised catfish. Food Technol. 43, 94-97.

Johnsen P. B., C. A. Kelly 1990. A technique for the quantitative sensory evaluation of farm-raised catish. J. Sen.s. Stud, 4, 189-199.

Johnsen P. B, H. K. Dupree 1991. Influence of feed ingredient on the flavor quality of farm raised catfish. Aquaculiture 96, 139-150.

Josephson D. B. 1991. Seafood, In: Volatile compounds in foods and beverages. Maarse eds. Dekker, USA, 179-202.

Li M., R. T. Lovell 1992 a. Growth, feed efficiency and body composition of second-and third-year channel catfish fed various concentrations of dietary protcin to satiety in production ponds. Aquaculture 103, 153-163.

I.j M.. R. T. [ovell $1992 \mathrm{~b}$. Comparison of satiate feeding and restricted fecding of channel catfish with various concentrations of dietary protein in production ponds. Aquaculture 103, 165-175.

Lorio W. J., P. W. Perschbacher, P. B. Johnsen 1992. Relationship between water quality, phytoplankton community and off-flavors in channel catfish (Ictalurus punctatus) production ponds. Aquaculture 106, 285-292.

Lovell R. T. 1983. Off-flavors in pond-cultured channel catfish. Wat. Sici. Tech. 15, 67-73.

Lovell R. T., L. A. Sackey 1973. Absorption by channel catfish of carthy-musty flavor compounds synthesized by cultures of blue green algac. Trans. Am. Fish. Soc. 102, 774-777.

Lovell R. T., M. Li 1992. Comparison of feed conversion, carcass yicld and muscle composition for second and third year channel catfish. Progress. Fish Cult. 54, 171-173.

Manthey M., V. Hilge, H. Rehbein 1988. Sensory and chemical evaluation of three catfish species (Silurus glanis, lctalurus punctatus, Clarias gariepinus) from intensive culture. Arch. Fischwiss. 38, 215-227.

Manthcy M., G. Karnop, H. Rehbein 1988. Quality changes of European catfish (Silurus glanis) from warm-water aquaculture during storage on ice. Int. J. Fond Sci. Technol. 23, 1-9.

Martin J. F., G. Izaguirre, P. Waterstrat 1991. A planktonic oscillataria species from Mississipi catfish ponds that produces the off-flavor 2-methylisoborneol. Wat. Res. $\mathbf{2 5}$, 1447-1451.

Medeiros L. C., C. D. Dudley, D. M. Medeiros 1986. Proximate composition and sensory evaluation of a sausage snack hall made from catfish and from pork. J. Food Sci. 51, 292-294.

Mitchell C. S. 1986. Lipid profile of select tissues of channel catfish (Ictalurus punctatus) as affected by harvesting scason and diet. PhD Thesis Mississipi State Univ. 184 p.

Paredes M. D. C., R. C. Baker 1987. Physical, chemical and sensory changes during thermal processing of three species of canned fish. J. Food Process. Preserv. 12, $71-81$.

Poulter R. G., B. Samaradivakrea, V. Jayaweera, I. S. R. Samaraweera, N. Chiniwasagam 1981. Quality changes in three Sri Lanka fish stored in ice. Trop. Sci. 23, 155-168.

Proteau J. P. 1993. Synthèse des principaux résultats et expérimentations réalisées depuis 1987 sur l'aquaculture 
du silure glane. Synthèse CEMAGREF Montpellier/AFSG, $28 \mathrm{p}$.

Reed R. J., G. R. Ammerman, T. C. Chen 1983. Chillpack studies on farm raised channel catfish. J. Food Stud. 48, $311-312$.

Rowlerson A., P. A. Scapolo, F. Mascarello, E. Carpene, A. Veggetti 1985. Comparative study of myosins present in the lateral muscle of some fish: species variations in the myosin isoforms and their distribution in red, pink and white muscle. J. Muscle Re.r. Cell Motil. 6, 601-640.

Schkenk D. 1994. The effect of 2-methyl isoborneol on cytochrome P450 expression in the channel catfish (Ictalurus punctatus). Aquaculture 120, 33-44.

Shepherd C. J., N. R. Bromage 1988. Intensive fish farming. BSP Prof. Books, Oxford.

Shreni K. D., A. K. Jafri 1978. Distribution pattern of some biochemical constituents in muscle of the common catfish Heteropneustes fossilis (Bloch). Fish Technol. 15, 121-123.

Sikorski Z. E., D. N. Scott, D. H. Buisson 1984. The role of collagen in the quality and processing of fish. Crit. Rev., Food Sci. Nutr. 20, 301-342.

Silva J. L., G. R. Ammerman 1993. Composition, lipid changes and sensory evaluation of two sizes of channel catfish during frozen storage. J. Appl. Aquac. 2, 39-49.

Smitherman R. O., R. A. Dunham, D. Tave 1983. Review of catfish breeding research.1969-1981 at Auburn university. Aquaculture 33, 197-205.

Smith D. W. 1988. Phytoplankton and catfish culture: a review. Aquaculture 74, 167-189.

Smith G., M. Hole, S. W. Hanson 1990. Assessment of lipid oxidation in Indonesian salted-dried marin catfish (Arius thalassinu.s). J. Sci. Food Agric. 51, 193-205.
Spanier A. M., P. B. Johnsen 1992. Molecular strategies for improving the quality of muscle food products. In: Molecular approaches to improving food quality and safety. D. Bhatnagar, T. E. Cleveland eds. Avi Book, Van Nostrand Reinhold, New York, 229-241.

Srikar L. N., H. S. Seshadari, A. A. Fazal 1989. Changes in lipids and proteins of marine catfish (Tachysurus dussumieri) during frozen storage. Int. J. Food Sci. 24, 653-658.

Tidwell J. H., H. R. Robinette 1990. Changes in proximate composition and fatly acid composition of fillets from channel catfish during a two-year growth period. Trans. Am. Fish. Soc. 119, 31-40.

Warren H. 1992. Catfish aquaculture in the USA. In: Production, environment and quality. G. Barnabé, P. Kestemont eds. Eur. Aquac. Soc., Spec. Publ. 18, 115-123.

Webster C. D., J. H. Tidwell, L. S. Gondgame, J. A. Clark, D. H. Yancey 1993. Effects of protein level and feeding frequency on growth and body composition of third-year channel catfish cultured in pond. J. Appl. Aquac. 2, 27-37.

Wilson R. P., W. E. Poe, T. G. Nemetz, J. R. MacMillan 1988. Effect of recombinant bovine growth hormone administration on growth and body composition of channel catlish. Aquaculure 73, 229-236.

Wolsters W. R., C. G. Lilyestrom, R. J. Craig 1991. Growth, yicld and dress-out percentage of diploid and triploid channel catfish on earthen ponds. Progress. Fish. Cult. 53, 33-36.

Yamaguchi K., J. Lavety, R. M. Love 1976. The connective tissues of fish. VII Comparative studies on hake, cod and catfish collagens. J. Food Technol. 11, 389-399. 